\title{
Long-term outpatient treatment of CMV retinitis with ganciclovir in AIDS patients
}

\author{
ROBERT W WEISENTHAL,' STEPHEN H SINCLAIR,' IAN FRANK,' AND \\ DONALD H RUBIN'?
}

From the 'Departments of Ophthalmology and Infectious Disease of the University of Pennsylvania School of Medicine, and the 'Department of Research Medicine, Veterans Administration Medical Center, USA

SUMMARY Cytomegaloviral retinitis was diagnosed in nine eyes of seven patients with acquired immune deficiency syndrome (AIDS) on the basis of the characteristic ocular findings and a positive culture for cytomegalovirus (CMV) obtained systemically. Treatment with ganciclovir was begun on a protocol which provided two weeks of inpatient therapy at daily doses of 2.5 to $10 \mathrm{mg} /$. $\mathrm{kg}$ followed by outpatient therapy at a reduced dosage three to six days per week. Outpatient maintenance dosage ranged from $15 \mathrm{mg} / \mathrm{kg}$ per week to $30 \mathrm{mg} / \mathrm{kg}$ per week. In seven eyes of six patients the treatment decreased retinal inflammation and stabilised the margins of the lesions. Six patients have tolerated long term maintenance therapy for 10-30 weeks. Six of seven patients $(85 \%)$ in this study developed side effects from ganciclovir which required periods of a reduction in dosage or interruption of therapy. The side effects from ganciclovir included neutropenia, thrombocytopenia, drug fever, and neuropathy. Physicians using ganciclovir in AIDS patients must watch for the signs of drug toxicity and adjust treatment accordingly. Ganciclovir appears to be a promising therapy for CMV retinitis, but further work is necessary to determine the best regimen for optimal efficacy with minimal side effects.

In $1982 \mathrm{CMV}$ retinitis was first reported in association with the acquired immunodeficiency syndrome (AIDS). Subsequent case reports have shown it to be the second most common ocular manifestation in patients with AIDS. ${ }^{L-\infty}$ In these patients the CMV retinitis was observed to be a progressive and unrelenting disease leading to blindness. Trials using vidarabine $^{31}$ acyclovir, ${ }^{3-5}$ or lymphokines ${ }^{5}$ have not produced an observable benefit.

Ganciclovir is a nucleoside analogue which inhibits viral replication by interfering with DNA synthesis within infected cells. "'t!2 The drug has been shown to be effective in producing temporary regression and stabilisation of CMV retinitis in patients with AIDS. ${ }^{1:-17}$ Recent reports have also documented prolonged stabilisation of CMV retinitis with ganciclovir on an outpatient regimen. Holland et al. showed maintenance therapy to be efficacious in 10 patients for at least three weeks and in one patient for up to 33 weeks. ${ }^{1 x}$ Henderly et al. treated 23 out-

Correspondence to Stephen H Sinclair, MD. Hahnemann University. $216 \mathrm{~N}$ Broad Street, 2nd Floor, Philadelphia, PA 19102, USA. patients for a similar duration with good results. ${ }^{19}$ Because of the importance of this therapy we now report our experience with ganciclovir in patients on maintenance therapy for up to 30 weeks. In our series a higher incidence and a wider variety of side effects with ganciclovir were observed than had been noted previously. In order to maintain patients on therapy lower dosages of ganciclovir were used; these dosages were shown to be more efficacious in stabilising the retinitis or treating recrudescence than has been previously reported.

\section{Subjects and methods}

Patients were entered into the drug protocol after informed consent was obtained if the patient was diagnosed as having AIDS, AIDS-related complex (ARC) based on US Clinical Disease Center recognised criteria, or was receiving immunosuppressive therapy for another illness which could not be reduced or discontinued. For the purposes of this report only those patients with AIDS are included. 
The CMV retinitis was confirmed ophthalmoscopically by a retina specialist on the basis of the characteristic clinical appearance. The presence of cotton-wool patches alone was not considered sufficient evidence for entrance into the study. All patients had a buffy coat, urine, throat, or tissue specimen that was culture positive for CMV.

All patients were given inpatient treatment for 14 days before being started on outpatient maintenance therapy. Inpatients were treated with an initial intravenous dose of ganciclovir at $10 \mathrm{mg} / \mathrm{kg}$ daily divided into two doses, or $7 \mathrm{mg} / \mathrm{kg}$ daily if the patient's peripheral white blood count (WBC) was less than $4 \times 10^{9} / 1-\mathrm{a}$ factor for poor tolerance of the full dose due to often observed severe neutropenia (unpublished data). This dose was adjusted for those with renal failure according to the creatinine clearance. If the therapy was discontinued owing to adverse side effects, the inpatient treatment period was extended and based on the length of time the drug was withheld.

Following hospital discharge outpatient maintenance therapy was administered on a schedule of three to six out of seven days by a visiting nurse at the patient's home. The initial outpatient maintenance dose was $5 \mathrm{mg} / \mathrm{kg}$ or less, and was administered once daily, based on the response to inpatient dosage and on the occurrence of side effects. Doses were adjusted for alterations in WBC or platelet count. Treatment was withheld if the patient developed a neutrophil count below $1 \times 10^{4} / 1$, if the neutrophil count fell to less than $30 \%$ of the admission value, or if the platelet count fell below $80 \times 10^{\%} / \mathrm{l}$. Ganciclovir was started again when the neutrophil count rose to $1.6 \times 10^{4} / 1$ or to $50 \%$ of the admission value, or when the platelet count reached $100 \times 10^{9} / \mathrm{l}$. If the retinitis progressed on maintenance therapy, the frequency of administration of dosage was increased.

Before they entered the study all patients had a complete history taken and physical examination done, including an eye examination performed by a retina specialist. The patients also had fundus examinations performed on a daily basis as inpatients and on a weekly basis as outpatients: Blood and urine samples were taken before entering the study and on inpatient days $1,3,5,7,10$, and 14 to monitor for haematological, renal, or hepatic side effects. The same studies were also performed on a weekly basis as outpatients. Urine and buffy coat cultures for CMV were obtained at baseline, and on days $1,3,5$, 6,10 , and 14 of inpatient therapy, as well as bimonthly during outpatient treatment.

\section{Results}

This study includes seven sequential AIDS patients who were treated for CMV retinitis involving nine eyes. Six of the seven patients had stabilisation or improvement of the retinitis during the two-week inpatient induction course (Table 1). One patient could not complete the inpatient regimen as a result of drug intolerance and eventually developed bilateral panretinal necrosis.

In six of seven patients the inpatient induction dosage was $10 \mathrm{mg} / \mathrm{kg}$ per day in two daily doses. One patient was on $7.5 \mathrm{mg} / \mathrm{kg}$ in divided doses because of pre-existing neutropenia. This patient was able to complete the induction regimen at this reduced dosage. Of the six patients started on a $10 \mathrm{mg} / \mathrm{kg} / \mathrm{day}$ regimen only two could tolerate the dosage and complete the induction therapy. Four patients developed neutropenia or thrombocytopenia secondary to ganciclovir, which necessitated completing the induction therapy at a reduced dosage or withdrawing therapy.

Six patients therefore entered the outpatient maintenance therapy protocol after discharge from the hospital. (For simplicity the outpatient maintenance dosage is listed as cumulative weekly dosage in $\mathrm{mg} / \mathrm{kg}$ because the frequency of administration and dosage per administration varied.) Three patients were begun on outpatient dosages of $15 \mathrm{mg} / \mathrm{kg} /$ week, given three days per week $(5 \mathrm{mg} / \mathrm{kg} /$ day $)$. One patient was begun on $25 \mathrm{mg} / \mathrm{kg} /$ week given over five days. Two patients were begun initially at a lower daily maintenance dose of $3.5 \mathrm{mg} / \mathrm{kg} /$ day given five days per week $(17.5 \mathrm{mg} / \mathrm{kg} / \mathrm{wk})$.

The cumulative weekly maintenance dosage required to control the retinitis varied between patients. In patient 3 the retinitis was controlled for 85 days with only $15 \mathrm{mg} / \mathrm{kg} /$ per week. A relapse occurred after an interruption of therapy, but the retinitis was again controlled with resumption at $25 \mathrm{mg} / \mathrm{kg} /$ week . In patient 6 the retinitis was controlled at a level of $17.5 \mathrm{mg} / \mathrm{kg}$ weekly for 80 days until he developed a cilioretinal occlusion necessitating the use of corticosteroids. Patient 7 was controlled on $17.5 \mathrm{mg} / \mathrm{kg} /$ week for 40 days, and then progression of a macular lesion necessitated an increase in dosage to $25 \mathrm{mg} / \mathrm{kg} /$ week, which was successful in resolving the new inflammation and stabilising the retinitis for 50 days. Owing to side effects the dosage was decreased to 15 $\mathrm{mg} / \mathrm{kg} /$ week, which stabilised the retinitis until day 123 , the endpoint of the study.

Patients 1 and 2 were initially started on $15 \mathrm{mg} / \mathrm{kg} /$ week maintenance dosage, which at that level caused side effects and was only partly effective in controlling the retinitis. Eventually the side effects necessitated discontinuation of therapy, and both patients eventually went blind. Patient 5 tolerated the inpatient dosage well and was started on an outpatient maintenance dose of $25 \mathrm{mg} / \mathrm{kg} /$ week, the 
Table 1 Course of therapy and response to ganciclovir of seven patients with AIDS and CMV retinitis

\begin{tabular}{|c|c|c|c|c|c|c|}
\hline & $\begin{array}{l}\text { Initial inpatient } \\
\text { treatment }\end{array}$ & $\begin{array}{l}\text { Extent of } \\
\text { retinopathy }\end{array}$ & $\begin{array}{l}\text { Acuity at } \\
\text { onset }\end{array}$ & Course/response during maintenance therapy & Final $V A$ & Side effects \\
\hline (1) & $\begin{array}{l}10 \mathrm{mg} / \mathrm{kg} / \mathrm{d} \text { then } \\
\text { decreased to } 7 \cdot 5 \\
\mathrm{mg} / \mathrm{kg} / \mathrm{d} \text { due to } \\
\text { neutropenia }\end{array}$ & $\begin{array}{l}\text { OD clear } \\
\text { OS CMV }(M, P, V)\end{array}$ & $6 / 6 \mathrm{OU}$ & $\begin{array}{l}\text { Regression with } 5 \mathrm{mg} / \mathrm{kg} / \mathrm{d}(3) ; \text { stopped after } 12 \\
\text { days due to side effects; developed progression } \\
\text { of retinitis at day } 30 ; \text { treatment restarted at day } \\
32 \text { at } 5 \mathrm{mg} / \mathrm{kg} / \mathrm{d}(6) \text { with stabilisation until day } \\
45 ; \text { treatment stopped due to side effects day } 56 ; \\
\text { recurrence of retinitis noticed on day } 75 \text { : no } \\
\text { response to lower treatment dosage }\end{array}$ & NLP OU & $\begin{array}{l}\text { Neutropenia } \\
\text { Drug fever }\end{array}$ \\
\hline (2) & $\begin{array}{l}10 \mathrm{mg} / \mathrm{kg} / \mathrm{d} \\
\text { decreased due to } \\
\text { neutropenia to } 5 \\
\mathrm{mg} / \mathrm{kg} / \mathrm{d}\end{array}$ & $\begin{array}{l}\text { OD CMV (ON, M, } \\
\text { P) } \\
\text { OS CWS }\end{array}$ & $\begin{array}{l}\text { LP OD } \\
6 / 5 \mathrm{OS}\end{array}$ & $\begin{array}{l}5 \mathrm{mg} / \mathrm{kg} / \mathrm{d}(3) ; \text { OS progressed, however dosage } \\
\text { not increased due to persistent neutropenia; } \\
\text { treatment stopped day } 72 ; \text { off treatment } \\
\text { progression of lesions OD and OS noted day } 9() ; \\
\text { treatment not restarted due to side effects }\end{array}$ & NLP OU & Neutropenia \\
\hline (3) & $10 \mathrm{mg} / \mathrm{kg} / \mathrm{d}$ & $\begin{array}{l}\text { OD CWS } \\
\operatorname{OSCMV}(M, M P, V)\end{array}$ & $\begin{array}{l}6 / 6 \text { OD } \\
6 / 15 \text { OS }\end{array}$ & $\begin{array}{l}5 \mathrm{mg} / \mathrm{kg} / \mathrm{d}(3) \text { stable for } 85 \text { days; patient } \\
\text { withdrew therapy and developed CMV }(\mathrm{ON}) \text {; } \\
\text { treatment restarted } 5 \mathrm{mg} / \mathrm{kg} / \mathrm{d}(5) \text { on day } 103 \\
\text { with retinitis stable until day } 160\end{array}$ & $\begin{array}{l}\text { 6/6 OD } \\
\text { LP OS }\end{array}$ & \\
\hline (4) & $\begin{array}{l}10 \mathrm{mg} / \mathrm{kg} / \mathrm{d} \\
\text { developed } \\
\text { neutropenia after } \\
5 \text { days: recurrent } \\
\text { attempts at } \\
\text { decreasing dosage }\end{array}$ & $\begin{array}{l}\text { OD CMV (MP) } \\
\text { OS clear }\end{array}$ & $6 / 7 \cdot 5 \mathrm{OU}$ & $\begin{array}{l}\text { Patient never completed induction therapy due } \\
\text { to interruptions in treatment because of side } \\
\text { effects at dosages } 2.5-10 \mathrm{mg} / \mathrm{kg} / \mathrm{d}\end{array}$ & $\begin{array}{l}\text { OD CF } \\
\text { OS } 6 / 7 \cdot 5\end{array}$ & $\begin{array}{l}\text { Neutropenia } \\
\text { Thrombo- } \\
\text { cytopenia }\end{array}$ \\
\hline (5) & $10 \mathrm{mg} / \mathrm{kg} / \mathrm{d}$ & $\begin{array}{l}\text { OD CMV (MP, V) } \\
\text { OS clear }\end{array}$ & $6 / 6$ OU & $\begin{array}{l}5 \mathrm{mg} / \mathrm{kg} / \mathrm{d}(5) \text { for } 28 \text { days stabilisation; } \\
\text { treatment stopped due to neutropenia/ } \\
\text { thrombocytopenia, restarted day } 39 ; 5 \mathrm{mg} / \mathrm{kg} / \mathrm{d} \\
\text { (5), and stabilised to day } 66 ; \text { developed } \\
\text { neutropenia; treatment again withheld with } \\
\text { progression of retinitis day } 84 ; \text { treatment } \\
\text { restarted day } 88 \text { at } 5 \mathrm{mg} / \mathrm{kg} / \mathrm{d}(3) \text { for } 12 \text { days but } \\
\text { stopped due to neutropenia; off treatment } \\
\text { progression of retinitis; therapy attempted at } \\
\text { lower dosage but was inadequate to stabilise } \\
\text { retinitis }\end{array}$ & NLP OU & $\begin{array}{l}\text { Neutropenia } \\
\text { Thrombo- } \\
\text { cytopenia }\end{array}$ \\
\hline (6) & $7.5 \mathrm{mg} / \mathrm{kg} / \mathrm{d}$ & $\begin{array}{l}\text { OD CMV (MP) } \\
\text { OS clear }\end{array}$ & $6 / 5 \mathrm{OU}$ & $\begin{array}{l}3.5 \mathrm{mg} / \mathrm{kg} / \mathrm{d}(5) \text { stabilised until day } 80 \text {; } \\
\text { developed occlusion cilioretinal artery OS with } \\
\text { retinal haemorrhages; varied dosage } 3 \cdot 5-6 \cdot 0 \\
\mathrm{mg} / \mathrm{kg} / \mathrm{d} \text { for } 20 \text { days due to bothersome } \\
\text { neuropathy; retinitis then stabilised until day } \\
310 \text { at } 6.0 \mathrm{mg} / \mathrm{kg} / \mathrm{d} \text { without further side effects }\end{array}$ & $\begin{array}{l}6 / 6 \mathrm{OD} \\
6 / 60 \mathrm{OS}\end{array}$ & Neuropathy \\
\hline (7) & $\begin{array}{l}10 \mathrm{mg} / \mathrm{kg} / \mathrm{d} \\
\text { developed } \\
\text { neutropenia; } \\
\text { decreased to } 7 \cdot 0 \\
\mathrm{mg} / \mathrm{kg} / \mathrm{d} \text { and then } \\
\text { to } 5 \mathrm{mg} / \mathrm{kg} / \mathrm{d}\end{array}$ & $\begin{array}{l}\text { OD CMV (MP) } \\
\text { OS CMV (MP) }\end{array}$ & $\begin{array}{l}6 / 120 \mathrm{OD} \\
6 / 6 \mathrm{OS}\end{array}$ & $\begin{array}{l}3 / 5 \mathrm{mg} / \mathrm{kg} / \mathrm{d}(5) \text { with stabilisation of peripheral } \\
\text { lesions but progression of macular lesion; } \\
\text { increased to } 5 \mathrm{mg} / \mathrm{kg} / \mathrm{d}(5) \text { with clearing of } \\
\text { macular region; developed neutropenia; } \\
\text { treatment decreased to } 3 \mathrm{mg} / \mathrm{kg} / \mathrm{d}(5) \text { with } \\
\text { stabilised retinitis to day } 175\end{array}$ & $\begin{array}{l}6 / 120 \text { OD } \\
6 / 6 \text { OD }\end{array}$ & Neutropenia \\
\hline
\end{tabular}

$\mathrm{CWS}=$ cotton-wool spots. $\mathrm{CMV}=$ cytomegalovirus retinitis. $\mathrm{O}=$ optic nerve disease $. \mathrm{M}=$ macula $. \mathrm{P}=$ peripheral. $\mathrm{MP}=$ midperipheral . $\mathrm{V}=$ vasculitis

$5 \mathrm{mg} / \mathrm{kg} / \mathrm{d}$ (3): number in parentheses denotes frequency of treatment per week.

highest initial outpatient dosage in the series. The therapy was effective in controlling the retinitis initially, but interruptions due to side effects led to progression of the inflammation. Eventually the patient could not tolerate even a lesser dose of $15 \mathrm{mg} /$ $\mathrm{kg} /$ week, and the retinitis progressed to blindness.

Side effects which necessitated interruption of treatment or reduction in dosage (or both) included neutropenia (five patients), thrombocytopenia (three patients), drug fever, and neuropathy (one patient).
The drug fever developed 12 days after starting outpatient therapy; the patient was admitted to hospital, at which time no other cause of the fever could be ascertained. The fever resolved with cessation of the drug.

Progression or recurrence of the retinitis was observed within 18 days of interruption of maintenance therapy. If the therapy could be restarted and continued, the retinitis was usually again stabilised or underwent regression. As discussed above, three 
patients could not tolerate an adequate dosage of medication, which led to unrelenting progression of the retinitis and blindness.

Conversion of urine and serum buffy coat CMV cultures to negative occurred in five of the six patients who received the complete induction course.

\section{Discussion}

Previous reports have documented the efficacy of ganciclovir for short term treatment of CMV retinitis. In a series of 13 patients reported by the DHPG (ganciclovir) Collaborative Treatment Group nine (69\%) patients showed improvement in visual acuity or a decrease in retinal inflammation with inpatient therapy. ${ }^{13}$ In several smaller series or case reports ganciclovir has been shown to produce clinical regression and to stabilise the retinitis for up to 30 days..$^{14-17}$

In two recently published reports ganciclovir (Syntex) or BW B7596) have been shown to be efficacious for long term therapy on an outpatient basis. Holland et al. treated 10 patients with continuous, uninterrupted therapy for at least three weeks. ${ }^{\text {ix }}$ Henderly et al ${ }^{19}$ treated 23 patients with interrupted therapy for two weeks to 15 months after the initial diagnosis of retinitis. In our study six patients were maintained on continuous therapy for 10 to 30 weeks. Therapy was interrupted only after development of significant side effects and was restarted as soon as the patient was capable of resuming therapy.

In combining the results of these three series we note that initial induction therapy produced clinical regression of the CMV retinitis in 48 of 50 patients, and outpatient therapy on a lower maintenance dose provided prolonged stabilisation of the retinitis in all patients. Without treatment CMV retinitis is rapidly progressive and destructive. Although ganciclovir inhibits viral replication, cessation of therapy will allow live virus to proliferate. In all patients in this series discontinuation of therapy led to recurrence of the retinal disease. While the goal of therapy is to deliver sufficient drug to control the retinitis, because of the significant rate of induction or exacerbation of severe side effects the physician must carefully monitor for both and adjust the dosages accordingly.

Maintenance dosages varied widely in these three studies both between patients and in any one patient over time. Henderly et al. followed up their patients on a standard dose of $25 \mathrm{mg} / \mathrm{kg} /$ week with prolonged stabilisation of the retinitis in $70 \%$ of patients for up to one year. ${ }^{19}$ Holland et al. did not specify cumulative weekly doses, but varied their dosage of maintenance therapy widely with good results in $60 \%$ of patients for up to 33 weeks. ${ }^{1 *}$ We were able to maintain three patients on ganciclovir for over 10 weeks with no reactivation of their retinitis at 15 to $17.5 \mathrm{mg} / \mathrm{kg} /$ week cumulative dosage.

Throughout maintenance therapy the dose of ganciclovir varied according to the patient's response to therapy and the side effects generated by the medication. It was not unusual to have reactivation of the CMV retinitis on a dosage of the medication which had previously controlled the retinitis. Four of 10 patients followed up by Holland et al. ${ }^{1 x}$ on continuous, uninterrupted maintenance therapy had reactivation of the retinitis, and in only one case was this attributed to an inadequate level of drug at 12.5 $\mathrm{mg} / \mathrm{kg} /$ week of ganciclovir. In the other cases maintenance dosages were higher, though cumulative weekly dosages were not specified. In these patients progression of the retinitis began from six to 17 weeks after the initiation of therapy.

In a study by Henderly et al., while the retinitis was stabilised at levels of $25 \mathrm{mg} / \mathrm{kg} / \mathrm{wk}, 34 \%$ of patients developed reactivation of the retinitis at this dosage on an average of 4.6 months after the start of therapy.$^{19}$ The retinitis was stabilised with an increase in dosage to $7.5 \mathrm{mg} / \mathrm{kg} /$ day for 10 days followed by an increased maintenance therapy of $35 \mathrm{mg} / \mathrm{kg} /$ week.

Three of six patients in our study suffered reactivation of the retinitis while on therapy with doses ranging from 15 to $17.5 \mathrm{mg} / \mathrm{kg} /$ week. The patients who had recurrences while on $15 \mathrm{mg} / \mathrm{kg} /$ week had been on maintenance therapy for less than two weeks. In one case increasing the dosage to $30 \mathrm{mg} / \mathrm{kg} /$ week stabilised the retinitis. In the second patient side effects prohibited increasing the levels; the retinitis slowly progressed as the therapy was tapered because of severe neutropenia; off therapy the retinitis progressed rapidly. The third patient, on $17.5 \mathrm{mg} / \mathrm{kg} /$ week, had progresson of macular retinal lesions without progression of peripheral lesions. Increasing the dosage to $25 \mathrm{mg} / \mathrm{kg} /$ week stabilised the macular lesions; neutropenia necessitated a decrease in dosage to $15 \mathrm{mg} / \mathrm{kg} / \mathrm{week}$, at which level, however, the retinitis did not progress further.

From review of the three series it appears that some patients could be maintained on low levels of drug without progression of the retinitis for extended periods while others developed reactivation even at higher levels of medication. The discrepancies must be due to variable resistance of the virus to the drug as well as to the varying degrees of immunodeficiency among the AIDS population.

In contrast to previous reports we observed in this series a higher incidence of patient toxicity to ganciclovir. Henderly et al. reported that three patients (13\%) developed neutropenia (leucocytes $\left.<1 \times 10^{9} / 1\right) .{ }^{19}$ Apart from one patient who developed dementia, no other side effects were reported. 
Holland et al. noted that five of 14 patients (36\%) developed reversible neutropenia requiring cessation of treatment, ${ }^{1 \times}$ but no other side effects from therapy were observed.

Six of the seven patients in this study developed significant side effects from therapy. The side effects included a reversible, dose related neutropenia (five patients), thrombocytopenia (three patients), drug fever, and neuropathy. One patient was unable to complete the two-week induction therapy owing to significant neutropenia and thrombocytopenia. Five of the six patients on long term maintenance therapy required a reduction in dosage or transient withdrawal from the drug. Side effects such as neutropenia were reversible in this series with discontinuation of the medication or reduction in dosage. With close follow-up the therapy could often be restarted within seven to 14 days.

Side effects of ganciclovir therapy which have been described in previous series and which were not seen in our patients include increased serum liver enzymes, eosinophilia, nausea, myalgias, anorexia, disorientation, hallucinations, rash, and phlebitis. ${ }^{13}$ In this study a cilioretinal artery occlusion was observed in one patient while on therapy, which to our knowledge has not been previously reported. Patients with AIDS are considered to have immunological mechanisms which produce embolic phenomena or vascular occlusion. Therefore it is unknown whether the occlusion was disease or drug related.

When the ganciclovir was discontinued and could not be restarted within two weeks, careful examination of the retina revealed a rim of inflammation to recur at the margins of the lesions which had previously been cleared. However, no new satellite lesions were observed in previously uninfected retina. The fellow eyes which were free of retinitis did not develop new lesions during such short periods. If therapy could be promptly restarted at doses which had previously controlled the retinitis, then the retinitis was often again controlled. However, if longer than two weeks elapsed before restarting therapy, an increased dose of ganciclovir was often necessary to control the recurrence, and in some cases the increased dose which was required could not be tolerated, leading to progression and blindness.

Our results suggest that in some patients a cumulative weekly dose of $15 \mathrm{mg} / \mathrm{kg} /$ week of ganciclovir may be sufficient to control retinitis that has been stabilised by a higher induction dosage. In this report we have also shown that $25 \mathrm{mg} / \mathrm{kg} /$ week of ganciclovir can reverse a recrudescence of retinitis which may occur after interruption of therapy.

The efficacy of ganciclovir in clearing CMV from the blood, urine, and other previously culture- positive sites has been clearly demonstrated in past studies. ${ }^{1314}$ Only one of our patients who received a full induction course of therapy had virus recoverable from a body fluid. It is of note that this patient's vision and retinal inflammation improved despite concomitant viraemia. Conversely, several patients on maintenance therapy in this series were culturenegative despite progression of their eye disease. One patient had CMV cultured from a bronchial wash but not from blood or urine at the time of worsening retinitis. This may reflect the inability to achieve drug levels sufficient to control tissue infection, though the levels may be sufficient to clear the blood and urine of virus. While all patients with ocular disease consistent with CMV had blood or urine cultures that were initially positive, negative blood or urine cultures during therapy did not necessarily predict the clinical response.

In conclusion, this pilot study adds to the previous reports and demonstrates ganciclovir to be a promising long-term treatment for CMV retinitis in the AIDS patient. In our series the intravenous drug was used in an outpatient setting for over 30 weeks with stabilisation and often regression of retinal disease. In contrast to previous reports, ganciclovir produced side effects in a higher proportion of patients. The spectrum of ganciclovir toxicity in this report includes neutropenia, thrombocytopenia, drug fever, and neuropathy. The physician using ganciclovir must be familiar with and monitor carefully the varied manifestations of ganciclovir toxicity in order to adjust therapy effectively.

\section{References}

1 Holland GN, Gottlieb MS, Yee RD, Schanker HM, Pettit TH. Ocular disorders associated with a new severe acquired cellular immunodeficiency syndrome. Am J Ophthalmol 1982; 93: 393402 .

2 Holland GN, Pepose JS, Pettit TH, Gottlieb MS, Yee RD, Foos RY. Acquired immune deficiency syndrome. Ophthalmology 1983; 90: 859-73.

3 Neuwirth J, Gutman I, Hofeldt AJ, et al. Cytomegalovirus retinitis in a young homosexual male with acquired immunodeficiency. Ophthalmology 1982; 89: 805-8.

4 Rodrigues MM, Palestine A, Nussenblatt R, Masur H, Macher AM. Unilateral cytomegalovirus retinochoroiditis and bilateral cytoid bodies in a bisexual man with the acquired immunodeficiency syndrome. Ophthalmology 1983; 90: 1577-82.

5 Bachman DM, Rodrigues MM, Chu FC, Straus SE, Cogan DC, Macher AM. Culture-proven cytomegalovirus retinitis in a homosexual man with the acquired immunodeficiency syndrome. Ophthalmology 1982; 89: 797-804.

6 Rosenberg PR, Uliss AE, Friedland GH, Harris CA, Small CB. Klein RS. Acquired immunodeficiency syndrome ophthalmic manifestations in ambulatory patients. Ophthalmology 1984; 90: 874-8.

7 Palestine A, Rodrigues MM, Macher AM, et al. Ophthalmic involvement in acquired immunodeficiency syndrome. Ophthalmology 1984; 91: 1092-4.

8 Pepose JS, Hilborne LH, Cancilla PA, Foos RY. Concurrent 
herpes simplex and cytomegalovirus retinitis and encephalitis in acquired immunodeficiency syndrome. Ophthalmology 1984: 91; $1669-77$.

9 Merritt JC, Callender CO. Adult cytomegalic inclusion retinitis. Ann Ophthalmol 1978; 10: 1059-63.

10 Mar E, Cheng Y, Huang E. Effect of 9-(1,3-dihydroxy-2 propoxymethyl) guanine on human cytomegalovirus replication in vitro. Antimicrob Agents Chemother 1983; 518: 24.

11 Frank FB, Chiou J, Cheng Y. Interaction of herpes simplex virus induced DNA polymerase with 9-(1,3-dihydroxy-2 propoxymethyl) guanine triphosphate. J Biol Chem 1984; 259: 1566-69.

12 Field AK, Davies ME, DeWitt C, et al. 9-\{[2-hydroxy-1(hydroxymethyl)ethoxy] methyl\} guanine: a selective inhibitor of herpes group virus replication. Proc Natl Acad Sci USA 1983; 80: $4139-43$.

13 Collaborative DHPG Treatment Study Group: Treatment of serious cytomegalovirus infections with 9-(1,3-dihydroxy-2propoxymethyl) guanine in patients with AIDS and other immunodeficiencies. N Engl J Med 1986; 314: 801-5.

14 Bach MC, Bagwell SP, Knapp NP, Davis KM, Hedstrom PS. 9(1,3-dihydroxy-2-propoxymethyl) guanine for cytomegalovirus infections in patients with acquired immunodeficiency syndrome. Ann Intern Med 1985: 103: 381-2.

15 Felsenstein D, D`Amico DJ, Hirsch MS, et al. Treatment of cytomegalovirus retinitis with DHPG. Ann Intern Med 1985: 103: $377-80$.

16 Palestine AG, Stevens G Jr, Lane HC, et al. Treatment of cytomegalovirus retinitis with dihydroxy propoxymethyl guanine. Am J Ophthalmol 1986; 101: 95-101.

17 Rosecan LR, Stahl-Bayliss CM, Kalman CM, Laskin OL. Antiviral therapy for cytomegalovirus retinitis in AIDS with dihydroxy propoxymethyl guanine. Am J Ophthalmol 1986; 101: 405-18.

18 Holland GN, Sakamoto MJ, Hardy D, Sidikaro Y, Kreiger AE, Frenkel LM. Treatment of cytomegalovirus retinopathy in patients with acquired immunodeficiency syndrome. Arch Ophthalmol 1986; 104: 1794-800.

19 Henderly DE, Freeman WR, Causey DM, Rao NA. Cytomegalovirus retinitis and response to therapy with ganciclovir. Ophthalmology 1987: 94: 425-8.

Accepted for publication 14 July 1989 